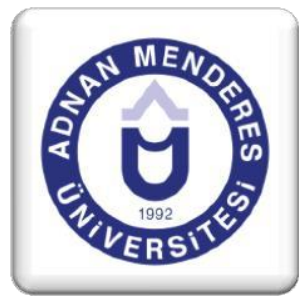

\section{Sosyal Bilgiler Öğretmen Adaylarının Ortadoğu Coğrafyası Hakkındaki Farkındalıkları ${ }^{1}$}

Esengül ŞAHIN ${ }^{2,}$ Asım ÇOBAN ${ }^{3}$

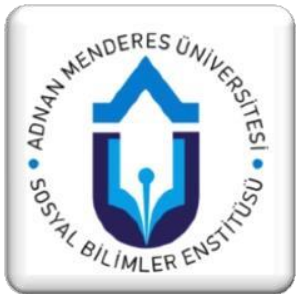

\title{
ÖZET
}

İnsanlık tarihinin bilinen en eski yerleşim yerlerinin başında gelen, adeta insanlığın doğduğu coğrafya Ortadoğu. Tarihin başlangıcı olarak kabul edilen yazının bulunduğu, doğuyla batıyı buluşturan ipek ve baharat yollarının düğümlendiği bu coğrafyayı 1902 yılında 'Middle East' Ortadoğu adıyla tanımlayan ilk kişi Amerikalı Amiral Alfred Thayer Mahan'dır ve Arabistan ile Hindistan arasındaki bölgeyi ifade etmek için kullanmıştır (Çelik ve Gürtuna, 2005: s,17). Ortadoğu semavi dinlere inananların ve aynı zamanda yerel inançları yaşatan toplumların bir arada yaşadıkları müstesna coğrafyalardan biridir. Irkları ve dilleri farklı olan insanların yaşadıkları bu eski medeniyet havzasına emperyal güçlerin ilgi duymaları 19. yüzyılın sonlarında başlar ve 20. yüzyılın başlarında da resmen işgal süreci başlar. Yüzyıllarca Müslüman Türk'ün idaresinde farklı din, dil ve ırklara mensup insanların bir arada barış ve huzur içinde yaşadıkları Ortadoğu coğrafyasında, Osmanlı Devletinin yıkılmasından sonra yeni yeni devletler kurulmuştur. Ortadoğu coğrafyasında en son kurulan devlet ise İsrail olmuştur. Bu çalışmanın amacı Sosyal Bilgiler öğretmen adaylarının Ortadoğu hakkındaki bilgi düzeylerini ve farkındalıklarını ortaya koymak, yetersizlik varsa önerilerde bulunmak, Ortadoğu coğrafyası ile ilgili doğru bilgi sahibi olmanın, ülkemizin geleceği açısından taşıdığı önemi ortaya koymaktır. Çalışmada tarafımızdan hazırlanan ve yoruma gerek kalmadan doğrudan bilgi gerektiren sorular içeren anket uygulanmıştır. Ankete gönüllülük esasına dayalı olarak Amasya Üniversitesi Eğitim Fakültesi Türkçe ve Sosyal Bilgiler Eğitimi Bölümünde eğitim gören 36 erkek, 64 kız olmak üzere 100 öğrenci katılmıştır. Çalışmada içerik analizi yöntemi kullanıldığı çalışmada en iyi bilinen Ortadoğu ülkesinin Irak olduğu, ancak katılımcıların yaklaşık dörtte birinin ise Türkiye'ye komşu Ortadoğu ülkeleri içinde İran ve Suriye'den bahsetmedikleri görülmüştür.

Anahtar kelimeler: Sosyal Bilgiler Öğretmen Adayları, Ortadoğu, Türkiye, Mısır, İsrail.

\section{Social Studies Teacher Candidates' Awareness About Middle east Geography}

\begin{abstract}
One of the earliest known settlements in human history is the Middle East where humanity is born. American Admiral Alfred Thayer Mahan was the first to define this geography in 1902, which was the beginning of history, where the silk and spice paths that connect the east and west were bound by the name " East East " in the Middle East, and used to express the region between Arabia and India (Celık and Gurtuna, 2005: s, 17). The Middle East is one of the exceptional geographies where believers in celestial religions and also societies that live local beliefs live together. The imperial powers' interest in this ancient civilization basin, where people of different breeds and languages live, began in the late 19th century and officially the occupation process began in the early 20th century. In the Middle East geography where people of different religions, languages and races live together in peace and tranquility in the administration of Muslim Turks for centuries, new states were established after the collapse of the Ottoman Empire. The most recently established state in the Middle East was Israel. The aim of this study is to reveal the knowledge levels and awareness of prospective social studies teachers about the Middle East, to make suggestions if there is insufficiency, to have accurate information about Middle East geography, to show the importance of our country for the future of our country. In this study, a questionnaire including questions requiring direct knowledge was prepared. The study included 36 boys and 64 girls from Amasya
\end{abstract}

\footnotetext{
${ }^{1}$ Bu çalışma 20-22 Nisan 2018 tarihinde Alanya'da düzenlenen II. Uluslararası Türk Coğrafyası Sosyal Bilimler Araştırmaları Kongresinde sözlü bildiri olarak sunulmuştur.

${ }_{2}^{2}$ Amasya Üniversitesi Eğitim Fakültesi, Türkçe ve Sosyal Bilimler Eğitimi Anabilim Dalı, Sosyal Bilgiler

Eğitimi Bilim Dalı, esenn1991@gmail.com

${ }^{3}$ Prof. Dr., Amasya Üniversitesi Eğitim Fakültesi, Temel Eğitim Bölümü, asim.coban@amasya.edu.tr
} 
University, Faculty of Education, Department of Turkish and Social Studies. The study used content analysis method is the best known of the Middle East countries of Iraq, but is about one quarter of the participants in the Middle East countries neighboring Turkey, Iran and Syria were seen they are not mentioned.

Keywords: Social Studies Teacher Candidates, Middle East, Turkey, Egypt, Israil.

\section{GİRIŞ}

İnsanlık tarihinin en eski yerleşim havzalarının başında gelen Ortadoğu, tarihin her döneminde önemini korumuş, her dönemin en hareketli coğrafyalarının başında gelmiştir. Eski uygarlıklar döneminde konumu, iklim ve toprak şartları bakımından taşıdığı değere bağlı olarak ilgi çeken Ortadoğu, yakın geçmişte ise tarihi ipek ve baharat yolları üzerinde yer almasıyla adeta doğu ile batı arasında bağlantıyı sağlayan bir medeniyet köprüsü özelliği kazanmıştır. 19. Yüzyılla birlikte zengin enerji rezervlerine sahip olduğu fark edilen Ortadoğu coğrafyası, sanayi inkılabının yaşandığı batı dünyası tarafından vazgeçilmez stratejik bölgeler arasında yerini almıştır. Özellikle 20.yüzyılda emperyal güçlerin güç gösterisi ve taktik savaşlarının uygulama sahasına dönüştürülen Ortadoğu coğrafyası beşeri kargaşanın odağı haline dönüştürülmüştür. İkinci dünya savaşından sonra bilimsel çalışmalarda ve uluslararası siyasette giderek kullanımı yaygınlaşan Ortadoğu, tarih boyunca çeşitli uygarlıklara ev sahipliği yapmış, farklı etnik, dini ve kültürel yapıların kaynaşmasına sahne olmuş bir mekandır (Mazman İtik, 2008: 1).

Eski dünya karalarının kesişim alanında yer alan Ortadoğu coğrafyası, strateji kuramcılarının başta gelen çalışma alanı konumuna gelmiştir. Modern sömürü sürecinin başta gelen hedef alanı durumundaki Ortadoğu, geleneksel yönetim mekanizmalarının yaşatıldığı, demokratik kazanımların uygulama alanı bulamadığı, monarşi coğrafyası olmaktan uzaklaşamamıştır. Toplumsal birliğin tesis edilemediği, inanç kaynaklı ayrışmanın geniş taban bulduğu, dikta anlayışıla halkın baskı altında tutulduğu Ortadoğu coğrafyası, günümüz dünyasında savaşların hiç eksik olmadığı, huzurun ve sükunetin bir türlü sağlanamadığı dram coğrafyasına dönüşmüştür. Ortadoğu, Doğu ile Batıyı, Akdeniz ile Hint Okyanusu'nu, Rusya ile sıcak denizleri birbirine bağlayan, aynı zamanda Doğu ile Batı arasındaki bütün ticarî ve kültürel bağlantıların yapıldığı bir bölgedir" (Sakin-Deveci, 2011: 282).

Bugün ABD’nin başlıca sömürü coğrafyası haline getirilen Ortadoğu kavramını ilk kez Amerikalı deniz stratejisi uzmanı Alfred Thayer Mahan, 1902 yılında Basra Körfezinin önemini ele aldığ "The Persian Gulf and International Relations" başlıklı yazısında kullanmıştır. Mahan, Ortadoğu terimiyle Arap Yarımadasıyla Hint Yarımadası arasında kalan bölgeyi kastetmiştir. İkinci Dünya Savaşında bölgeye konuşlanan İngiliz Güçlerine "İngiliz Ortadoğu Komutanlığı” adı verilmesiyle Ortadoğu kelimesi dünya çapında tanınıp, kullanılmaya başlanmıştır" (Burhan, 2008: 26).

Bütün bu farklı kullanımlar ve kapsamın değişkenliği dikkate alınmak şartıyla bugün Ortadoğu kavramının dar anlamda Türkiye, İran, Mezopotamya, Arap Yarımadası, Körfez ülkeleri ve Mısır'ı içine alacak şekilde kullanılmakta olduğunu söylemek mümkündür. $\mathrm{Bu}$ kavramın kapsamının daha da genişletilerek Libya, Sudan, Eritre, Cibuti ve Afganistan'ı da 
içerecek şekilde geniş anlamda kullanıldığı; bazı çalışmalarda ise kapsamın daha da genişletilerek Atlas Okyanusundan Mısır'a kadar tüm Kuzey Afrika'yı içine alacak genişlikte kullanılmakta olduğu da görülmektedir. Hatta bazı çalışmalarda Ortadoğu kavramının kapsamına Kafkasların ve Orta Asya'nın da dâhil edilerek kapsamın iyice genişletildiği de dikkat çekmektedir" (Dursun, 2003: 4-5).

Dünya ham petrol rezervinin üçte ikisine (Elmas, 2012: 58) ve doğalgaz rezervlerinin yarısına (Öztürkler, 2009: 66) sahip olan Ortadoğu'nun bu özelliğinden dolayı dışarıdan müdahalelerin ve iç savaşların gerçekleştiği bir saha olmaktadır. Ayrıca bu petrol zenginliği ülkenin politikasını ve dolayısıyla diğer ülkelerle olan ilişkilerini de etkilemektedir (Özdemir, 2012: 48).

21.yüzy1lda ABD’nin bölgede uygulamak istediği Büyük Ortadoğu Projesi (BOP), bölgeyi daha da derin bir çıkmaza sürüklemiş, bunun sonucu olarak din tandanslı ayrılıklar daha da derinleşmiş, bağımsız ülkeler, parçalanma sürecine girmişlerdir. Nitekim Ortadoğu, Arap Baharı olarak tanımlanan ve demokrasinin getirilmesi gerekçesiyle mevcut yönetimlerin yıkıldığı ancak, yerine de istikrarlı bir yönetim mekanizmasının kurulamadığı, terör örgütlerinin yuvalandığı bir coğrafya özelliği kazanmış, çıkan kargaşa ortamında çok sayıda insan hayatını kaybederken, milyonlarca insan da mülteci durumuna düşmüştür.

Üzerinde yer aldığımız Ortadoğu coğrafyası günümüzde iç savaşların hiç bitmediği, terör yapılanmalarının sıradanlaştığı, uyuşturucu ve silah tüccarlarının kazançlarına kazanç kattıkları bir coğrafyaya dönüşmüştür. Bu istikrarsılılı coğrafyasında yaşanan her olay, ortaya çıkan her türlü terör yapılanması ülkemizi etkilemiş, bir taraftan Türkiye tehditle karşı karşıya kalırken, diğer taraftan da ülkelerini terk eden milyonlarca mültecinin başlıca sığınağı haline dönüşmüştür.

\section{İlgili Araştırmalar}

Literatüre bakıldığında benzer çalışmalardan biri Tunçel'in (2002), “Türk Öğrencilerin Zihin Haritalarında İslam Ülkeleri” başlıklı çalışmasıdır. Bu çalışmada farklı üniversitelerin coğrafya bölümlerinde öğrenim görmekte olan 400 öğrenci örneklem kapsamında değerlendirilmiştir. Katılımcı öğrencilerden dünya haritası çizmeleri, çizdikleri bu harita üzerinde de İslam ülkelerini göstermeleri istenmiştir. Çalışmanın örneklemini coğrafya bölümünde öğrenim görmekte olan öğrenciler oluşturduğu için, çalışmada beklenen dönüt alınmış, öğrencilerin büyük çoğunluğu 20'nin üzerinde İslam ülkesini harita üzerinde gösterebilmişlerdir.

Sosyal Bilgiler öğretmen adaylarının Ortadoğu algısını belirlemeye yönelik çalışmalardan biri Yılmaz ve Yiğit'in 2010 yılında yayınlanan "Sosyal Bilgiler Öğretmen Adaylarının Avrupa, Ortadoğu ve Türkiye’ye Komşu Ülkelere İlişkin Algıları” isimli makaledir. Bu çalışmada genel olarak Ortadoğu kavramının öğretmen adaylarında oluşturduğu algııı belirlemeye yönelik sorular sorulmuş, alınan cevaplar üzerinde değerlendirmeler yapılmıştır. Çalışmada katılımcıların komşu ülkelere bakışında dost-düşman yaklaşımının belirgin olduğu, bu ülkelerin Türkiye politikalarının genel olarak aleyhte bir niteliğe sahip olduğu ve 
komşularla aramızdaki en önemli ve birleştirici bağın İslam dini olduğu sonucu ortaya çıkmıştır.

Bu konuda yapılan bir başka çalışma Aksoy ve Karaçalı'nın 2014 yılında yayınlanmış olan "Sosyal Bilgiler Öğretmen Adaylarının Ortadoğu Algısı (Sinop Üniversitesi Örneği) başlıklı çalışmadır. Bu çalışmada Sinop Üniversitesi Eğitim Fakültesinde 2012-2013 akademik öğretim yılında 3.sınıfta okuyan öğretmen adaylarından 20 kişiye standartlaştırılmış 7 tane açık uçlu soru sorulmuş, alınan cevaplar yorumlanarak katılımcıların Ortadoğu algıları ortaya konulmuştur. Bu çalışmada öğrencilerin Ortadoğu algılarındaki ilk konunun iç karışıklık olduğu, en önemli ülkenin Irak, katılımcıların \%85'inin bir Ortadoğu ülkesi olduğunda hem fikir oldukları Türkiye'nin İran'la ilişkilerin geliştirilmesini istedikleri sonucunu ortaya koymuştur.

\section{Araştırmanın Amacı}

$\mathrm{Bu}$ araştırmanın temel amacı, üzerinde yer aldığımız ve insanlık tarihinin her döneminde başta gelen medeniyet havzalarından biri haline gelmiş Ortadoğu coğrafyası hakkında Sosyal Bilgiler öğretmen adaylarının alg1 düzeylerini ortaya koymaktır. Tarihi, kültürel ve dini bağlarla bağlantılı olduğumuz; günümüzde kargaşa ve tehdit coğrafyası haline gelmiş olan Ortadoğu ülkeleri hakkında Sosyal Bilgiler öğretmen adaylarının farkındalıklarını ortaya koymak ve sonuca bağlı olarak çeşitli öneriler ortaya koymak amaçlanmıştır.

\section{YÖNTEM}

Olgu bilim deseninde gerçekleştirilen bu çalışma, Sosyal Bilgiler lisans öğrencilerinin gerek siyasi coğrafya, gerekse ülkeler coğrafyası konularının içerisinde yer alan "Ortadoğu" kavramını nasıl algıladıklarını ve Ortadoğu coğrafyasında bulunan ülkeler hakkında farkındalıklarını belirlemek amacıyla yapılmıştır. Araştırmada, Sosyal Bilgiler öğretmen adaylarının Ortadoğu ve Ortadoğu ülkeleri algısını belirlemek amacıyla içerik analizinden oluşan nicel araştırma teknikleri kullanılmış olup, öğrencilerle anket formları üzerinden açık uçlu görüşme yapılmıştır. Görüşmede cinsiyet, ailevi bilgiler ve Ortadoğu ile ilgili bilgi düzeylerinin analizini sağlayacak sorular sorulmuştur.

\section{Çalışma Grubu}

Araştırmanın çalışma grubunu; 2017-2018 eğitim öğretim yılında Amasya Üniversitesi Sosyal Bilgiler Öğretmenliğinde öğrenim gören ve gönüllülük esasına bağlı olarak seçilen 100 öğrenci oluşturmaktadır. Araştırmada farklı sınıf düzeylerindeki öğrencilerin seçilmesi gerek orta dereceli okullarda, gerekse Eğitim Fakültesinde okutulan Ülkeler Coğrafyası ve Siyasi Coğrafya derslerinde Ortadoğu ile ilgili konuların bulunmasıdır. Ayrıca konu ile ilgili bilgi edinebilecekleri daha önceki sınıf düzeylerinde diğer coğrafya derslerinin de bulunması görüşmenin farklı sınıf düzeylerinde yapılmasının diğer nedenidir. Araştırmaya öğretmen adaylarının çoğunlukla kız öğrencilerden ibaret olmasından dolayı 64 ü kız, 36 s1 erkek olmak üzere 100 öğrenci katılmıştır. 


\section{Veri Toplama Aracı}

Araştırmada veri toplama aracı olarak standartlaştırılmış açık uçlu görüşme formu kullanılmıştır. Görüşme formunda bulunan soruların oluşturulmasında, odak grup görüşme yönteminden yararlanılmıştır. Odak grup görüşmesinde hedef, katılımcıların, diğerlerinin görüşlerini duyabildiği ve buna göre kendi görüşleri üzerinde düşünebildiği sosyal bir ortamda paylaşımda bulunmalarını sağlamaktır. Konu, Sosyal Bilgiler öğretmenliği 4.sınıfların 'Günümüz Dünya Sorunları'" dersinde tartışmaya açılmış, öğrencilerin çoğunlukla üzerinde durdukları konular, görüşme formuna alınmıştır. Görüşme formunda kişisel ve ailevi bilgilerin yanında, Ortadoğu hakkında öğrenci görüşlerini ortaya koymayı hedefleyen görüşme formu kullanılmıştır. Görüşme formunda yer alan 6 tane açık uçlu sorudan yararlanarak Ortadoğu ülkelerinin yönetim biçimleri, Türkiye ile olan ilişkileri ve ortak sorunlar hakkında Sosyal Bilgiler öğretmen adaylarının farkındalıkları ortaya konulmaya çalışılmıştır.

Bu çalışmanın yapı geçerliğine ilişkin analizlerinde açımlayıcı ve doğrulayıcı faktör analizi birlikte kullanılmıştır. Literatürde her iki analizin kullanılmasının yapı geçerliğine ilişkin kanıtları ortaya koymada etkili olduğu, ancak ilk olarak hangi analizin yapılması konusunda araştırmacıların seçim yapması gerektiği belirtilmektedir (Çokluk, Şekercioğlu ve Büyüköztürk, 2010).

Çalışmada kullanılan ölçeğin güvenirliğine ilişkin analizlerde ise farklı yöntemlerle iç tutarlılık katsayıları elde edilmiş ve sonuçların birbirini desteklediği görülmüştür. $\mathrm{Bu}$ sebeple, güvenirlik analizlerinin de yeterli düzeyde gerçekleştirildiği ve görüşme formunun güvenirliği test edilmiştir.

\section{Verilerin analizi}

Sosyal Bilgiler Öğretmenliği programında okuyan öğretmen adaylarına Ortadoğu ile ilgili sorulan sorulara verdikleri cevaplar, içerik analizi tekniği kullanılarak çözümlenmeye çalışılmıştır. İçerik analizinde temel amaç, toplanan verileri açılayabilecek kavramlara ve ilişkilere ulaşmaktır (Yıldırım ve Şimşek, 2008: 227). İçerik analizi insan davranışları üzerinde doğrudan olmayan yollarla çalışmaya imkân tanıyan ve özellikle sosyal bilimlerde sıklıkla kullanılan bir tekniktir (Büyüköztürk vd., 2010). İçerik analizinin salt bir betimleme ve tasvir aracı ya da tekniği olmadığı, aksine çıkarım yapma yoluyla sosyal gerçeğin belirli boyutlarını araştıran bir yöntem olduğu bilinmektedir. İçerik analizinin; seçici, sınıflandırıcı ve nicelleştirici bir yöntem olduğu da söylenebilir (Gökçe, 2006). Araştırmamıza gönüllülük esasına göre katılan Sosyal Bilgiler öğretmen adaylarının Ortadoğu konusundaki farklı1ıklarını belirlemek amacıyla hazırlanan açık uçlu görüşme formundaki 6 maddeden elde edilen veriler nicel hale dönüştürülerek betimsel istatistik tabloları elde edilmiş ve yorumlanmıştır. 


\section{BULGULAR VE YORUM}

Tablo: 1 Katılımcıların cinsiyete göre dağılımı

\begin{tabular}{lcc}
\hline Cinsiyet & N & \% \\
\hline Erkek & 36 & 36 \\
Kadın & 64 & 64 \\
Toplam & 100 & 100 \\
\hline
\end{tabular}

Ortadoğu coğrafyası hakkında farkındalıklarını ortaya koymak üzere gönüllülük esasına göre görüşme yapılan Sosyal Bilgiler öğretmen adayı sayısı 100 kişi olup, 36 s1 erkek öğrencilerden, 64 ü de kız öğrencilerden oluşmaktadır (Tablo: 1). Farklı sınıf düzeylerine sahip olan öğretmen adaylarının 26 tanesi halen bir köy yerleşmesinde ikamet ediyorken, 74 tanesi de şehir yerleşmesinde ikamet etmektedir. Araştırmamıza katılan toplam 100 öğretmen adayından, bugüne kadar yurt dışına bir defa da olsa çıkış yapanların sayısı 9 kişi, hiç yurt dışına çıkış yapmayanların sayısı ise 91 kişidir.

Tablo: 2 Öğretmen Adaylarının Mezun Oldukları Ortaöğretim Kurumları

\begin{tabular}{lcc}
\hline Mezun olunan okul & N & \% \\
\hline Anadolu Lisesi & 35 & 35 \\
Anadolu Öğretmen Lisesi & 6 & 6 \\
Anadolu Teknik Meslek Lisesi & 32 & 32 \\
Teknik Lise & 6 & 6 \\
Açı Lise & 2 & 2 \\
Diğgr Eğitim Kurumları & 19 & 19 \\
Toplam & 100 & 100 \\
\hline
\end{tabular}

Araştırmamıza katılan Sosyal Bilgiler öğretmen adaylarının mezun olunan ortaöğretim kurumlarına göre dağılışına bakıldığında, \% 35'inin Anadolu Lisesinden, \% 32'sinin Anadolu Teknik Meslek Lisesinden, \% 19'unun diğer orta dereceli eğitim kurumlarından, \% 6'sının Anadolu Öğretmen Lisesinden, \% 6'sının Teknik Liseden ve \% 2'sinin ise Açık Liseden mezun oldukları görülmektedir (Tablo: 2). Ailelerin gelir düzeylerine göre katılımcıların dağılımına bakıldığında \% 42'sinin 1000-2000 TL aralığında gelire sahip olduğu görülürken, \% 27'sinin aylık geliri 2000-3000 TL aralığında, \% 12'sinin $1000 \mathrm{TL}$ den az, \% 12'sinin 3000-4000 TL aralı̆̆ında ve \% 7'sinin ise $4000 \mathrm{TL}$ den fazla gelire sahip ailelerden oluştukları görülmektedir.

Tablo: 3 Ortadoğu'da bulunduğuna inandığınız 5 ülkenin adını söyleyiniz? Sorusuna verilen cevapların dağılımı

\begin{tabular}{lc}
\hline Ülke adı & N \\
\hline Irak & 83 \\
Suriye & 76 \\
İran & 74 \\
Filistin & 56 \\
İsrail & 32 \\
Suudi Arabistan & 23 \\
Türkiye-Lübnan & 19 \\
Misir & 12 \\
Katar-Kuveyt-Türkmenistan & 7 \\
Ürdün-Libya-Azerbaycan-Afganistan & 5 \\
\hline
\end{tabular}


I.Soru: Ortadoğu'da bulunduğuna inandığınız 5 ülkenin adını söyleyiniz? Sorusuna verilen cevaplar içinde en fazla söylenen ülke 83 adetle Irak olmuştur. Sosyal Bilgiler öğretmen adaylarının Ortadoğu denildiğinde Irak’tan sonra 76 öğrenci tarafından II. sırada belirttikleri ülke de Suriye olmuştur (Tablo: 3). Türkiye'nin kara sınırıyla komşu bulunduğu Ortadoğu ülkelerinin (İran-Irak ve Suriye) tüm katılımcılar tarafından istisnasız öncelikle belirtilmesi beklenirken, öğretmen adaylarının yaklaşık \% 25 i özellikle İran ve Suriye'den bahsetmemişlerdir. Komşularımız olan İran, Irak ve Suriye'den sonra katılımcıların 56 frekansla belirttikleri ülke Filistin olmuştur. İsrail'in 32 katılımcı tarafından belirtildiği çalışma da, Suudi Arabistan 23, Türkiye ile Lübnan 19 kişi tarafından belirtilmiştir. Bazı çalışmalarda Ortadoğu coğrafyasına dâhil edilen Libya ve Afganistan katılımcılar tarafından 5 er defa belirtilmiş, ancak Ortadoğu coğrafyasında yer almayan Türkmenistan 7, Azerbaycan 5, Kazakistan ve Özbekistan 4 er defa, Ermenistan 2, Kırgızistan, Bulgaristan, Gürcistan ise 1 er defa belirtilmiştir.

Hangi ülkelerin Ortadoğu'da yer aldığını sorduğumuz soruya verilen cevaplardan hareketle, öğretmen adaylarının Ortadoğu ülkeleri hakkında yeterli düzeyde bilgiye sahip olduklarını söylemek olası görülmemekte, bu konuda önemli ölçüde bilgi eksikliğinin olduğu açıkça görülmektedir.

Tablo: 4 Ortadoğu'da Türkiye ile dost olduğuna inanılan ülkeler

\begin{tabular}{lc}
\hline Ülke adı: & N \\
\hline Fikri yok & 29 \\
Filistin & 26 \\
Azerbaycan & 16 \\
Katar & 15 \\
Dostumuz yok & 13 \\
Afganistan-İran & 10 \\
Türkmenistan & 9 \\
Irak-Suriye & 7 \\
Özbekistan & 6 \\
Lübnan-Misır & 5 \\
Ürdün-Suudi Arabistan & 4 \\
Kuveyt-Yemen-Kazakistan & 3 \\
Pakistan-Kırgızistan-KKTC-BAE & 2 \\
Gürcistan-Bulgaristan-Hindistan-Libya-Tayland & 1 \\
\hline
\end{tabular}

2.Soru: Ortadoğu'da Türkiye ile dost olduğuna inandığınız ülkeler hangileridir? Sorusuna verilen cevaplara bakıldığında 29 öğrenci 'ffikrinin olmadığını" belirtirken, 13 katılımcı da "dostumuz yok" diye cevap vermiștir (Tablo: 4). Ortadoğu coğrafyasında yer almayan Azerbaycan 16 katılımcı tarafından "dost ülke" olarak belirtilirken, son yıllarda Ortadoğu'da Türkiye ile ilişkileri oldukça iyi seyreden Katar 15 öğretmen adayı tarafından dost ülke olarak değerlendirilmiştir. Son yıllarda ilişkilerimizin iyi olmadığı, zaman zaman sıcak çatışmaya varabilecek gerginliklerin yaşandığı Irak ve Suriye'yi dost ülke olarak kabul eden öğretmen adayı 7'dir. Bir Orta Asya Türk Cumhuriyeti olan Türkmenistan 9, Özbekistan ise 6 katılımcı tarafından Ortadoğu Coğrafyasındaki dost ülkeler grubunda 
değerlendirilmiştir. Yine darbeyle işbaşına gelen ve Türkiye'nin diplomatik ilişkilerini askıya aldığı Mısır 5 kişi tarafından dost kabul edilmiştir.

Son dönemde Katar'a uygulanan ambargo ${ }^{2}$ dolayısıyla iyi ilişkiler içinde olmadığımız Suudi Arabistan 4, Orta Asya Türk Cumhuriyeti Kazakistan 3, Uzak Doğu ülkesi Pakistan, Orta Asya Türk Cumhuriyetlerinden Kırgızistan, KKTC ve körfez ülkesi BAE 2, öğretmen adayı tarafindan dost ülke kategorisinde değerlendirilmiştir. Uzak Doğu ülkelerinden Hindistan ile Tayland, Balkan ülkesi Bulgaristan ve Kafkasya ülkesi Gürcistan 1 er katılımcı tarafından dost ülke olarak belirtilmiştir. Tabloya bakıldığında Sosyal Bilgiler öğretmenliği öğrencilerinin Türkiye'nin dış politikasıyla çok ilgilenmedikleri, bulunduğumuz coğrafyada bulunan ülkelerle aramızda yaşanan olaylardan haberdar olmadığı, ülke sorunlarına beklenen düzeyde sorumlu yaklaşmadığı görülmektedir. Kaldı ki ülkenin içinde bulunduğu bölgesel ve küresel sorunlara en fazla ilgi duyması, sorunlarımızın çözümüne yönelik stratejik düşünme becerilerinin en fazla gelişmesi beklenen öğretmen adaylarının başında Sosyal Bilgiler öğretmen adayları gelmektedir.

Tablo: 5 Ortadoğu'da yaşanan en önemli olaylar

\begin{tabular}{lc}
\hline Olayın tanımı & N \\
\hline Suriye İç Savaşı & 39 \\
Kudüs sorunu & 36 \\
Irak'ın işgali-Fikri yok & 20 \\
Filistin sorunu & 19 \\
Mısır'da darbe & 11 \\
Arap baharı & 10 \\
Saddam'ın idamı- Petrol sorunu & 7 \\
Terör olayları-Işid Örgütü & 6 \\
Suriyeli mülteciler & 5 \\
Gazze sorunu-Kuzey Irak referandumu & 4 \\
Katar krizi-Su sorunları-Kaddafi'nin öldürülmesi & 3 \\
Süleyman Şah türbesi-Fırat kalkanı harekatı-Uçak krizi- & 2 \\
Türkmenler sorunu-Kerkük-Musul-Türkiye'de 15 Temmuz & \\
darbe girişimi & \\
Yaser Arafat'ın ölümü-Türk askerinin başına çuval & 1 \\
geçirilmesi-Mavi Marmara olayı-Türkiye'de terör olayları & \\
\hline
\end{tabular}

3.Soru: Ortadoğu'da yakın geçmişte yaşanan ve size göre en önemli olay hangisidir? Sorusuna verilen cevaplara bakıldığında, 39 katılımcının en önemli olay olarak gördüğü gelişmenin Suriye'deki iç savaş olduğu görülmektedir (Tablo: 5). Suriye iç savaşından sonra önem sıralamasında 36 görüşle II. sırada yer alan olayın Kudüs sorunu olduğu ortaya çıkmaktadır. Dolayısıyla öğretmen adaylarına göre Ortadoğu'nun günümüzdeki öncelikli sorunu Suriye'deki iç savaş ve Kudüs'ün karşı karşıya olduğu durumdur. Araştırmanın belki de en önemli sonucu 20 katılımcının Ortadoğu'nun en önemli olayı nedir sorusuna 'fikrim yok" diye cevap vermesidir. Türkiye'de yaşayan, aynı zamanda üniversite eğitimi almaya devam eden, iletişim araçlarının bu kadar gelişme gösterdiği bir dönemde, Ortadoğu'da

\footnotetext{
${ }^{2}$ Haziran 2017 de Katar'ın 'Ortadoğu'da terörizme, özellikle de bölge ülkelerinde İran destekli gruplara destek verdiği, Müslüman Kardeşler örgütüne hem siyasi, hem de finansal destek sağladığı"' gerekçesiyle Mısır, Suudi Arabistan, BAE, Bahreyn ve Yemen tarafindan ambargo uygulanmaya başlanmıştır.
} 
yaşanan en önemli olay nedir? Sorusuna ' fikrim yok" denilmesi cevap vermeme isteğinden de kaynaklanmış olabilir.

Katılımcıların \%20 oranında öneme değer bulduğu bir diğer olay Irak'ın işgalidir. Filistin sorununun, 19 defa önem taşıyan öncelikli sorun olarak ifade edildiği araştırmada, 11 katılımc1 Mısır'da darbe konusunu, 7 katılımcı Saddam Hüseyin'in idam edilmesi ve petrol sorunlarını, 6 katılımcı terör olaylarını ve Işid örgütünü, 5 katılımcı Suriyeli mültecileri, 4 katılımc1 Gazze sorunu ve Kuzey Irak referandumunu, Ortadoğu'nun en önemli olayı olarak görmüştür. Ayrıca bu soruya 3 er katılımcı öncelikli sorun olarak Katar krizi, su sorunları ve Kaddafi'nin öldürülmesini önemli sorun olarak gördüklerini cevap olarak vermişlerdir. Süleyman Şah Türbesi, Fırat Kalkanı Harekâtı, Uçak krizi, Türkmenlerin sorunları, MusulKerkük sorunu ve Türkiye'de 15 Temmuz kalkışmasını 2'şer defa önemli sorun olarak bulan katılımcılar olmuştur. Ayrıca Sosyal Bilgiler öğretmen adaylarına sorulan, Ortadoğu'da size göre yakın geçmişte yaşanan en önemli olay nedir? Sorusuna 1'er katılımcı Yaser Arafat'ın ölümü, Türk askerinin başına çuval geçirilmesi, Türkiye'de yaşanan terör olayları ve Mavi Marmara olayını önemli bulduklarını ifade etmişlerdir.

Öğretmen adaylarının önemli bir kısmının Ortadoğu'da, çevremizde yaşanan olaylara karşı duyarlı olduğu, geçmişte yaşanan bazı olayların, günümüzde yaşanan olaylardan daha fazla önem taşıdığını vurgulamış, sınırlı sayıda katılımcı tarafından da olsa ülkemizi ilgilendiren olaylar tereddütsüz daha fazla öneme haiz olay olarak görülmüştür.

Bazı milli olaylara duyarlılık sevindirici olmakla beraber, parçası olduğumuz ve yaşanan gelişmelere duyarsız kalamadığımız Ortadoğu olayları hakkında, öğretmen adaylarının değerlendirmelerine bakıldığında gerek orta dereceli okullarda, gerekse yükseköğrenimde bölge ülkelerinin daha iyi tanınmasını sağlayacak ders veya konuların yeterli olmadığı sonucuna varılabilmektedir. Özellikle coğrafya derslerinin her sınıf düzeyinde ve günümüz gerçekleriyle örtüşen bir müfredata sahip olarak okutulmasının önemi ve gerekliliği ortaya çıkmaktadır. Türkiye'de yaşanan sorunların bölgesel olaylardan bağımsız okunması, doğru teşhis konulmasına engel olacaktır. Teşhisin doğru konulmadığı yerde de istenilen çözüm asla gerçekleşmeyecektir.

Tablo: 6 Ortadoğu ülkeleri ile Türkiye arasındaki benzer veya ortak olan özellikler

\begin{tabular}{lc}
\hline Ortak benzerlikler & N \\
\hline İnanç birliği & 38 \\
Fikri yok & 27 \\
Tarih ve kültür & 26 \\
Coğrafi konum & 23 \\
Doğal kaynaklar & 14 \\
Terör olayları & 6 \\
Benzer veya ortak özelliğimiz yok & 4 \\
Dil-Kutsal değerler & 4 \\
Diş politika-Ekonomik durum & 3 \\
ABD ile ilişkiler- Manevi değerler & 2 \\
Küresel güçlerle ilişkiler-Manevi değerlerin zayıflaması-Gelişmekte & 1 \\
olan ülke oluşları & \\
\hline
\end{tabular}


4.soru: Ortadoğu ülkeleriyle Türkiye arasında benzer veya ortak olan özellikler nelerdir? Sorusuna verilen cevaplara bakıldığında 27 katılımcı bu konuda fikrinin olmadığını belirtirken, 4 katılımcı ise ortak veya benzer özelliğimizin olmadığını belirtmiştir (Tablo: 6). Ortadoğu ülkeleri ile aramızda inanç birliği var diyen katılımcı sayısı 38 olup, ortak veya benzer özelliklerimiz sorusuna en fazla verilen cevap olarak belirginlik kazanmıştır. Öğretmen adaylarından 26'sı tarih ve kültürü, 23'ü coğrafi konumumuzu, 14'ü doğal kaynaklarımızı, 6'sı ise terör olaylarını ortak veya benzer özelliklerimiz arasında değerlendirmiştir. Doğal kaynaklar arasında benzer veya ortak özelliklere sahip olduğumuzun ortaya konulması da düşündürücüdür.

Dil ve kutsal değerlerimizin benzer veya ortaklığına vurgu yapan katılımcı sayısı 4 , dış politika ve ekonomik durumların ortak veya benzerliğine inanan katılımcı sayısı 3, ABD ile ilişkiler manevi değerler bakımından ortak veya benzer özelliklere sahip olduğumuzu düşünenlerin sayısı ise 2'dir. Ayrıca birer katılımcı da küresel güçlerle işbirliğini, manevi değerlerin giderek zayıflamakta olduğunu ve gelişmekte olan ülke kategorisinde yer almışlığı ortak veya benzer özellik olarak değerlendirmişlerdir. İlgili soruya verilen cevapların analizine bakıldığında öğretmen adaylarının Ortadoğu ülkeleri hakkında yeterli bilgi birikimine sahip olmadıkları sonucuna varılmakta, eğitim öğretim programlarının ülke ve bölge gerçekleriyle örtüşecek tarzda yeniden revize edilmesini zorunlu hale getirmektedir.

Tablo:7 Ortadoğu ülkelerinde demokrasinin benimsendiğine inanılan ülkeler

\begin{tabular}{lc}
\hline Ülke adı & $\mathbf{N}$ \\
\hline Fikri yok & 50 \\
Demokrasi yok & 13 \\
Türkiye & 18 \\
İran & 8 \\
Irak & 8 \\
İsrail & 5 \\
Filistin & 4 \\
Suudi Arabistan & 4 \\
KKTC & 2 \\
Suriye & 2 \\
Misir-Katar-Lübnan-BAE-Ermenistan-Yunanistan-Tayland & 1 \\
\hline
\end{tabular}

5.soru: Ortadoğu ülkelerinden demokrasinin işlevsel olduğuna inandığınız ülkeler hangileridir? Sorusuna verilen cevaplara bakıldığında, katılımcılardan 50 tanesi bu konuda fikrinin olmadığını belirtirken, 13 katılımcı da Ortadoğu ülkeleri içinde demokrasinin işlevsel olduğu bir ülkenin bulunmadığını belirtmişlerdir (Tablo: 7). Sosyal Bilgiler öğretmen adaylarından oluşan katılımcıların Ortadoğu'da demokrasinin varlığına en fazla sayıyla katıldıkları ülke Türkiye olmuştur. Türkiye'de demokrasinin işlevsel olduğunu beyan eden katılımcı sayısı 18, Ortadoğu'da demokrasinin uygulandığı ülke olarak İran'1 ve Irak'1 belirtenlerin sayısı ise 8 er kişidir.

İsrail'in 5 katılımcı tarafından bölgede demokrasinin işlevsel olduğu ülke olarak gösterildiği araştırmada Filistin ve Suudi Arabistan'da 4'er katılımcı tarafından demokrasinin yaşatıldığı bir ülke olarak ifade edilmiştir. Yine Ortadoğu coğrafyasında demokrasinin işlevsel olduğuna inanılan ülkeler olarak KKTC ile Suriye'de 2'şer katılımcı tarafından demokratik 
bulunmuştur. Yine bölge ülkelerinden olan Misır, Katar ve Lübnan birer katılımcının demokratik ülke kategorisinde yer alırken; Ortadoğu'da olmayan Yunanistan, Ermenistan ve Uzak Doğu ülkesi Tayland'da birer katılımcının demokratik bulduğu ülke olarak araştırma sonuçlarında yer almıştır.

$\mathrm{Bu}$ soruya verilen cevaplara bakıldığında öğretmen adayı olan katılımcıların Ortadoğu ülkelerinin yönetim mekanizmaları hakkında yeterli bilgiye sahip olmadıkları, ayrıca Türkiye ve İsrail'de demokrasinin işlevsel olmasıyla ilgili olarak verilen cevapların yetersizliğine bakıldığında, öğretmen adaylarının demokrasinin tanımlanması konusunda yeterli bilgi birikimine sahip olmadıkları açıkça görülebilmektedir.

Tablo:8 Öğretmen adaylarının Ortadoğu'nun geleceği ile ilgili öngörüleri

\begin{tabular}{lr}
\hline Ortadoğu'nun geleceği & N \\
\hline Fikri yok & 28 \\
Bağımsız Kürt Devleti kurulur & 17 \\
Türkiye nüfuz alanını genişletir & 13 \\
Ortadoğu'da harita değişir & 13 \\
İsrail genişler & 11 \\
Demokrasi yerleşir & 9 \\
Mülteci sorunu büyümeye devam eder & 8 \\
Türkiye savaşa girer & 8 \\
Su savaşları çıkar & 5 \\
Açlık sorunu baş gösterir & 5 \\
Petrol tükenir & 3 \\
Sömürü devam eder & 3 \\
\hline
\end{tabular}

6.soru: Ortadoğu'nun geleceği ile ilgili öngörüleriniz nedir? Sorusuna öğretmen adaylarından 28 katılımcı "fikrinin olmadığını" belirtmiş, 17 katılımcı ise gelecekte Ortadoğu'da bağımsız bir Kürt devletinin kurulabileceği öngörüsünde bulunmuştur (Tablo: 8). Sosyal Bilgiler öğretmen adaylarından 13 tanesi gelecekte Türkiye'nin Ortadoğu'da nüfuz alanını genişleteceğini belirtirken, yine 13 öğretmen adayı da Ortadoğu'da haritanın değişebileceği öngörüsünde bulunmuştur. Ortadoğu'nun geleceği hakkında fikir beyan eden öğretmen adaylarından 11 tanesi İsrail'in genişleyeceğini, 9 tanesi ise Ortadoğu'ya demokrasinin geleceğini belirtmiştir.

Öğretmen adaylarından 8'i Türkiye'nin Ortadoğu'da bir savaşa gireceğini belirtirken, yine 8 öğretmen adayı da Ortadoğu'da mülteci sorununun giderek artacağını ifade etmiştir. Ortadoğu'da su nedenli savaşın çıkacağı öngörüsünde bulunan katılımcı sayısı da 5, bölgede açlık sorunlarının başlayabileceğini belirten katılımcıların sayısı da yine 5'tir. Ortadoğu'nun geleceği hakkında katılımcıların 3'ü petrolün tükeneceğini, 3'ü de sömürü sürecinin devam edeceğini belirtmiştir.

Ortadoğu'nun geleceği hakkında öngörüde bulunan öğretmen adaylarının bölgenin geleceği ile ortaya koydukları görüşlerde de günümüz Ortadoğu'sunda olduğu gibi karışık senaryolardan bahsedilmiştir. Bugün olduğu gibi gelecekte de Ortadoğu coğrafyasının geleceğini kestirebilmek pek olası görülmemektedir. Ancak kesin olan şu ki, Ortadoğu 
günümüzdeki istikrarsızlı̆g 1 geleceğe taşıyacak, stratejik hesapların odağında yer almaya devam edecektir.

\section{SONUÇ VE TARTIŞMA}

Sosyal Bilgiler öğretmen adaylarının Ortadoğu coğrafyası hakkındaki farkındalıklarını belirlemek üzere yapılan bu çalışmada, elde edilen bulgulara bakıldığında, katılımcıların önemli bir kısmı Ortadoğu'da bulunan ülkeleri tam olarak ifade edememiş, Uzak Doğuda bulunan Hindistan, Pakistan ve Tayland gibi ülkeler Ortadoğu ülkeleri olarak belirtilmiştir. Ayrıca Balkan ülkelerinden Bulgaristan ve Yunanistan da Ortadoğu ülkeleri olarak belirtilirken, Kafkas ülkelerinden Gürcistan ile Ermenistan'da yine Ortadoğu coğrafyasında belirtilmiştir. Bazı uzak doğu ülkeleriyle, Balkan ve Kafkas ülkelerinin Ortadoğu ülkesi olarak belirtilmiş olmasında ise tamamen coğrafi bilgi yetersizliği açıkça görülmektedir. Katılımcıların çoğunluğunun Ortadoğu ülkesi olarak öncelikle belirttiği ülkeler Irak, Suriye ve İran olmuştur. Sinop Üniversitesinde yapılan bir benzer çalışmada ise, katılımcıların çoğunluğu (\% 80 i) İran, Irak, Filistin ve İsrail'in Ortadoğu ülkesi olduğunu belirtmişlerdir (Aksoy ve Karaçal1, 2014: 24).

Ortadoğu'da Türkiye'nin dostu olan ülkelerle ilgili olarak öğretmen adaylarının 1/3 ü 'ffikrinin olmadığını" belirtmiş, 13 katılımcı da "dostumuzun olmadığını" belirtmiştir. Ortadoğu'da dostumuz olarak en fazla kabul gören ülkenin Filistin, daha sonra da Katar olduğu belirtilmiştir. Bölgede yer alan ülkelerden dostumuz diye belirtilmiş ülkelerin daha çok Sovyetler Birliği dağıldıktan sonra bağımsız olan Türk Cumhuriyetleri olduğu görülmekte, katılımcıların çoğunluğu bölgede Türkiye'nin dostunun olmadığı kanaatini taşımaktadır.

Öğretmen adaylarına göre Ortadoğu'da yaşanan en önemli olaylar, Suriye iç savaşı, Irak'ın işgali ve Filistin-Kudüs sorunu olarak belirtilmiştir. Ortadoğu'da yakın geçmişte yaşanan hemen her olaydan, sınırlı sayıda katılımcı tarafından da olsa mutlaka bahsedilmiş, özellikle de Türkiye'yi ilgilendiren olaylar önemli bulunmuştur.

Ortadoğu ülkeleri ile Türkiye arasındaki benzerliklerin genel olarak inanç, tarih ve kültür birliği, doğal kaynaklar ile terör konuları gibi tarihi ve yerel konularda yoğunlaştığı görülmektedir. Dolayısıyla Ortadoğu'nun bize yabancı bir coğrafya parçası olmadığı, inançtan, ekonomik niteliklere kadar birçok konuda benzerliğimizin olduğu, katılımcılar tarafindan ifade edilmiştir.

Ortadoğu ülkelerinde demokrasinin işlevsel olup-olmadığıyla ilgili sorulan soruya katılımcıların yarısı ' fikrinin olmadığını" belirtirken, önemli sayıda katılımcı da 'bölgede demokrasinin olmadığını"' ifade etmiştir. Ortadoğu'da en işlevsel demokrasinin yaşatıldığı ülke olarak Türkiye belirtilmiş, bunu İran ve Irak izlemiştir. Yine Aksoy ve Karaçalı'nın Sinop Üniversitesinde yaptıkları çalışmada Ortadoğu'nun en önemli ülkesi olarak Türkiye gösterilmiş, Türkiye'yi İran, Suriye ve Irak izlemiştir. Bu durumu Aksoy ve Karaçalı "politik güce" bağlamışlardır (Aksoy ve Karaçalı, a.g.m.). Ortadoğu ülkeleri hakkında, 
katılımcıların en az bilgi sahibi oldukları konunun, bölge ülkelerinin yönetim yapılarıyla ilgili olduğu ortaya çıkmıştır.

Öğretmen adaylarının Ortadoğu'nun geleceğiyle ilgili en çok endişe duydukları konunun Bağımsız Kürt Devletinin kurulması olduğu, Ortadoğu'nun gelecekte haritasının değişeceği, ancak Türkiye'nin de genişleme sürecine gireceği öngörüsü ortaya çıkmıştır. Ortadoğu'nun geleceği ile ilgili farklı konularda, birbiriyle zaman zaman çelişen, zaman zaman da örtüşen gelişmelerin olabileceği ortaya konulmuştur. Aksoy ve Karaçalı'nın çalışmalarında katılımcılara göre gelecekte, Ortadoğu'da karışıklıkların ve sömürünün devam edeceğinin düşünüldügü ortaya çıkmıştır.

\section{ÖNERILER}

Türkiye'nin özel konum şartlarından kaynaklanan bölgesel sorunlar dikkate alınarak, üniversite öğrencilerinin, özellikle de Sosyal Bilimler alanında öğrenim görmekte olan öğrencilerin Ortadoğu coğrafyası hakkındaki algı düzeylerinin analizi konusunda bundan sonra da düzenli bir periyotta araştırma yapılması büyük önem taşımaktadır. Üniversitelerimiz ülkesine ve bölgesine duyarlı bireyler yetiştirmeye önem vermeli, istenilen kazanımları sağlayacak öğrenme programları geliştirilmelidir.

Öğretmen adaylarının üzerinde yer aldığımız ve dünyanın her dönemde en karışık ve istikrarsız coğrafyasını oluşturan Ortadoğu coğrafyasını çok iyi tanımaları ve bölgenin geleceğini en doğru biçimde okuyabilmeleri için alınması gereken önlemlere gelince:

1- Türkiye'de eğitim-öğretimin hemen her kademesinde coğrafya derslerine daha fazla önem verilmesi, strateji kuramcılarının, Devleti yönetenlerin ve asker bürokratların en önemli dayanağını oluşturan coğrafya okur-yazarlığının bir formasyon olarak kazandirılmasi.

2- Gerek bölge güvenliği, gerekse ekonomik ilişkilerin geliştirilmesinde, öncelikli ve verimli alan olan yakın çevrenin hem doğal, hem de beşeri coğrafyasının ayrıntılı bir biçimde öğretilmesinin sağlanması.

3- Her eğitim kademesinde coğrafya müfredatlarının güncellenmesi, yakın çevreye daha geniş alan birakılması.

4- Ülkeler Coğrafyası derslerinde, Ortadoğu'ya daha geniş yer verilmesi, komşu ülkelerin daha ayrıntılı bir biçimde tanıtılması.

5- Lise düzeyinden başlamak üzere, yükseköğretimin tüm birimlerine 'Türk Dünyas1 Coğrafyası"' derslerinin konulması.

6- Lisans ve ön lisans programlarının tamamında öncelikle zorunlu, en azından seçmeli dersler arasına 'Siyasi Coğrafya'" dersinin konulması.

7- Orta dereceli okullarda öğrenim gören başarılı öğrenciler, yakın olan Türk coğrafyasından başlamak kaydıyla, çağdaş Türk Ülkelerine götürülerek ödüllendirilmeli, eski medeniyet havzamız ve Türk Dünyası yerinde tanıtılmalıdır. 


\section{KAYNAKLAR}

AKSOY, B, KARAÇALI, H. (2014). Sosyal Bilgiler Öğretmen Adaylarının Ortadoğu Algısı (Sinop Üniversitesi Örneği) UTEB- Uluslararası Türk Eğitim Bilimleri Dergisi, Yı1: 2 Say1: 2. Tokat.

BURHAN, A. (2008). Filistin-İsrail Çatışması ve Hamas. Yayınlanmamış Yüksek Lisans Tezi. Süleyman Demirel Üniversitesi Sosyal Bilimler Üniversitesi, Isparta.

BÜYÜKÖZTÜRK, Ş., ÇAKMAK, E. ,AKGÜN, Ö. E., KARADENIZ, Ş. ,DEMIREL, F. (2010). Bilimsel Araştırma Yöntemleri, Ankara: Pegem Yayınları.

ÇELIK, S. GÜRTUNA, A. (2005). Büyük Ortadoğu Projesi ve Türkiye’ye Etkileri, Global Strateji Enstitüsü Ankara, s, 17.

ÇOKLUK, Ö. , ŞEKERCIOĞLU, G. ve BÜYÜKÖZTÜRK, Ş. (2010) Sosyal Bilimler İ̧̧in Çok Değişkenli İstatistik, Ankara: Pegem Akademi.

DURSUN, D. (2003). Ortadoğu Neresi?-Subjektif Bir Kavramın Anlam Çerçevesi ve Tarihi. Ayllk Strateji ve Analiz e-Dergisi, Sayı: 10, ISSN: 1303-9814.

ELMAS, B. (2012). Ortadoğu'daki Enerji Kaynaklarının Önemi ve Türkiye Üzerinden Taşınması Ille Türkiye'nin Kazandı ̆̆ Jeopolitik Konum. Yayınlanmamış Yüksek Lisans Tezi. Atılım Üniversitesi Sosyal Bilimler Enstitüsü, Ankara.

GÖKÇE, O. (2006). İçerik Analizi Kuramsal ve Pratik Bilgiler, Ankara: Siyasal.

MAZMAN İTIK, Ü. (2008). Türkiye'nin Ortadoğu Ülkeleri İle Ekonomik Ve Ticari İlişkileri Üzerine Bir Değerlendirme. Yayınlanmamış Yüksek Lisans Tezi. Cumhuriyet Üniversitesi Sosyal Bilimler Enstitüsü, Sivas.

ÖZDEMIR, Ç. (2012). Ortadoğu ve Arap Baharı (Türkiye Demokratik Bir Ülke Olarak Ortadoğu'da Model Olabilir Mi?). Yayınlanmamış Yüksek Lisans Tezi. Dumlupınar Üniversitesi Sosyal Bilimler Enstitüsü, Kütahya.

ÖZTÜRKLER, H. (2009). Ortadoğu Ülkelerinin Ekonomik Yapılarının Temel Özellikleri. Ortadoğu Analiz Dergisi, Cilt: 1, Say1: 6, 65-71, Ankara.

ÖZTÜRKLER, H. (2009). Ortadoğu Ülkelerinin Enerji Kaynaklarının Öneminin EkonomiPolitik Bir Değerlendirmesi. Ortadoğu Analiz Dergisi, Cilt: 1, Say1: 7-8, 74-79, Ankara.

SAKIN, S. DEVECİ, C. (2011). Ortadoğu Kavramı ve Sınırları Üzerine Bir Değerlendirme. History Studies. ABD ve Büyük Ortadoğu İlişkileri Özel Sayısı, 281-293, Samsun.

TUNÇEL, H. (2002). Türk Öğrencilerinin Zihin Haritalarında İslam Ülkeleri. Firat Üniversitesi Sosyal Bilimler Dergisi, Cilt:12, Sayı:2, 83- 103, Elazığ.

YILDIRIM, A, ŞİMŞEK, H. (2008). Sosyal Bilimlerde Nitel Araştırma Yöntemleri, Ankara: Seçkin Yayıncılık. 
YILMAZ, K., YİĞIT, Ö. (2010). Sosyal Bilgiler Öğretmen Adaylarının Avrupa, Ortadoğu ve Türkiye'ye Komşu Ülkelere İlişkin Algıları. Hacettepe Üniversitesi Eğitim Fakültesi Dergisi, Say1: 38, 318-334, Ankara. 